\title{
Specific Metabolic Fingerprint of a Dietary Exposure to a Very Low Dose of Endosulfan
}

\author{
Cécile Canlet, Marie Tremblay-Franco, Roselyne Gautier, Jérôme Molina, Benjamin Métais, \\ Florence Blas-Y Estrada, and Laurence Gamet-Payrastre
}

INRA, TOXALIM (Research Centre in Food Toxicology), UMR 1331, INRA/INP/UPS, 31027 Toulouse, France

Correspondence should be addressed to Laurence Gamet-Payrastre; laurence.payrastre@toulouse.inra.fr

Received 13 July 2012; Accepted 20 November 2012

Academic Editor: M. Teresa Colomina Fosch

Copyright (c) 2013 Cécile Canlet et al. This is an open access article distributed under the Creative Commons Attribution License, which permits unrestricted use, distribution, and reproduction in any medium, provided the original work is properly cited.

\begin{abstract}
Like other persistent organochlorine pesticides, endosulfan residues have been detected in foods including fruit, vegetables, and fish. The aim of our study was to assess the impact of a dietary exposure to low doses of endosulfan from foetal development until adult age on metabolic homeostasis in mice and to identify biomarkers of exposure using an ${ }^{1} \mathrm{H}$-NMR-based metabonomic approach in various tissues and biofluids. We report in both genders an increase in plasma glucose as well as changes in levels of factors involved in the regulation of liver oxidative stress, confirming the prooxidant activities of this compound. Some metabolic changes were distinct in males and females. For example in plasma, a decrease in lipid LDL and choline content was only observed in female. Lactate levels in males were significantly increased. In conclusion, our results show that metabolic changes in liver could be linked to the onset of pathologies like diabetes and insulin resistance. Moreover from our results it appears that the NMR-based metabonomic approach could be useful for the characterization in plasma of a dietary exposure to low dose of pesticide in human.
\end{abstract}

\section{Introduction}

Many epidemiological studies have shown that exposure to pesticides is a risk factor for human health, as evidenced by the positive correlation between professional exposure to these compounds and an increase in the incidence of various human diseases (reviewed in Merhi et al. [1]). The general population is also exposed to pesticides mainly via food intake. Thus many people have a lifelong exposure to low doses of pesticides, the impact of which on human health is not yet known.

Organochlorine (OC) pesticides are among the most frequent contaminants found in the environmental compartments because they persist in the environment and bioaccumulate in organisms, partly due to their lipophilic properties [2]. Endosulfan is a chlorinated cyclodiene pesticide which was first severely restricted then banned in 2006 in several European Union countries. Nevertheless, the general population continues to be exposed: like other persistent organochlorine pesticides, endosulfan residues have been detected in several foods including fruits, vegetables, and fish
[3]. There is an evidence that endosulfan is acutely poisonous to humans through both accidental and intentional exposure [4].

Endosulfan is classified by the World Health Organisation as a moderately hazardous (class II) pesticide [5]; however, it is genotoxic [6] and is an endocrine disrupter displaying xenooestrogenic activity [7]. Endosulfan has been shown to be toxic to the liver, kidney, nervous system, and reproductive organs of laboratory animals [8-10]. Exposure to this compound can modify the activity of some enzymes involved in oxidative stress and xenobiotic metabolism, as well as testosterone metabolism and clearance [11]. Recently Casabar et al. [12] showed that endosulfan was a strong activator of the pregnane $\mathrm{X}$ receptor (PXR) and an inducer of cytochrome P450 (CYP) 2B6 and CYP3A4, so it may have an impact on the metabolism of their substrates. A recent study by Ozmen et al. [13] showed that treating rabbits with endosulfan led to changes in glucose levels, histological degenerative changes in the pancreas and endocrine disturbances. Endosulfan may also be a risk factor for children whose parents have been exposed since the accumulation of 
organochlorine compounds in fat tissue during the mother's life can expose the child during pregnancy and breast feeding [2]. The transfer of OC pesticides from mother to foetus was demonstrated via the detection of the pesticides in the maternal umbilical cord, placenta, and in samples taken from the newborn [2]. Moreover, Pathak et al. [14] suggested that levels of some organochlorine pesticides such as endosulfan in the maternal fluid or tissue are associated with preterm delivery and increased foetal oxidative stress. Pre- and postnatal exposure to endosulfan is reported to affect biogenic amines and amino acids in the prefrontal cortex [15]. Whilst the toxicological effects of endosulfan have been studied in vitro and in vivo, the impact of long-term exposure to low doses through dietary intake in animal models from the foetal stage to adulthood has not yet been reported.

An NMR spectroscopy-based metabonomic approach coupled with pattern recognition technology is an effective way of characterizing the biochemical response of an organism to contaminant exposure and identifying potential biomarkers of exposure $[16,17]$. Metabonomics has proven to be a very useful tool in investigating the biochemical effects of many toxic compounds [18-20].

In our study we developed a mouse model of diet to assess the impact of dietary exposure to a low dose of endosulfan on metabolic homeostasis in mice exposed from foetal development until adult age. We investigated biomarkers of dietary exposure using an ${ }^{1} \mathrm{H}$-NMR-based metabonomic approach in various tissues and biofluids.

\section{Materials and Methods}

2.1. Reagents. Endosulfan was purchased from Fluka (Riedel de Haën, France) and was added as a component of rodent nuggets at a dose of $30 \mu \mathrm{g}$ per $\mathrm{kg}$. This dose allowed the mice to ingest the equivalent of the Acceptable Daily Intake (ADI $0.006 \mathrm{mg} / \mathrm{kg}$ food/day)) defined for humans by the Joint FAO/WHO Meeting on Pesticide Residues [21] that was extrapolated for mice on the basis of mean body weight. Information on the toxicity of endosulfan was obtained from Agritox (AFSSA, 2005. http://www.dive.afssa.fr/agritox/) or ExToxNet (ExToxNet: http://extoxnet.orst.edu/).

2.2. Preparation of Pesticide-Enriched Feed. Endosulfan $(1.5 \mathrm{mg})$ was dissolved in $1 \mathrm{ml}$ methanol, and then $100 \mu \mathrm{L}$ of this solution (containing $150 \mu \mathrm{g}$ endosulfan) was mixed with methanol (final quantity of endosulfan $150 \mu \mathrm{g}$ ). The whole resulting solution (containing $150 \mu \mathrm{g}$ endosulfan) was mixed with acetone $(9 \mathrm{~mL})$ and dispersed on $10 \mathrm{~g}$ of the vitamin mixture powder (vitaminic mixture 200, Scientific animal Food Engineering (Safe), France). The vitamin powder containing $150 \mu \mathrm{g}$ endosulfan was then homogenized in a rotavapor for 30 minutes at $45^{\circ} \mathrm{C}$ to evaporate the solvent and then mixed for 50 minutes at room temperature with the remaining quantity of vitamin mixture ( $40 \mathrm{~g})$ needed to make the rodent nuggets $(5 \mathrm{~kg})$. The vitamin powder enriched with endosulfan was then sent to the INRA animal feed preparation unit (UPAE INRA Paris France) where vitamins (1\%) and mineral complement (7\%) were mixed with the other components of the rodent nuggets. The presence of endosulfan was quantified by Eurofins (Nantes, France). The final quantity was around $30 \mu \mathrm{g} / \mathrm{kg}$ of food. Control feed was prepared as described above with a mixture of methanol/acetone $(1 / 1, \mathrm{~V} / \mathrm{V})$ but lacking pesticide. Control feed was analyzed for the presence of the endogenous pesticide (endosulfan) and also for the presence of the most common pesticides found in the environment (including the organophosphorus pesticide organochloride, pyrethroid, and PCB). Results showed that nuggets in control food do not contain pesticides at the detectable level $(0.01 \mathrm{mg} / \mathrm{kg})$.

2.3. Animals. Ten-week-old female and male C57 BL/6J mice were purchased from Charles River Laboratories, France. Mean body weights were 20 and $24 \mathrm{~g}$ for females and males, respectively. Females ( 5 per lot) were fed from mating until gestation and lactation with the control diet or the diet enriched with pesticide. Weaned pups (from 6 to 8 per lot) were then fed with the same diet as their respective parent for an additional period of 11 weeks. Food consumption was monitored and the body weight was measured. Animals were sacrificed by cervical dislocation, and the spleen, liver, and kidneys were weighed. Bone marrow was extracted from the femur of treated or nontreated males and females as previously described $[1,22]$. The liver was excised, weighed, and frozen rapidly in liquid nitrogen. In addition, blood samples were taken from the facial artery of each animal and added to a glass vial containing heparin (Multivette, SARSTED, Germany).

\subsection{Metabonomic Studies}

2.4.1. Sample Preparation for ${ }^{1}$ HNMR Spectroscopy. Plasma samples $(100 \mu \mathrm{L})$ were diluted with $500 \mu \mathrm{L}$ deuterium oxide $\left(\mathrm{D}_{2} \mathrm{O}\right)$ before being placed in $5 \mathrm{~mm}$ NMR tubes.

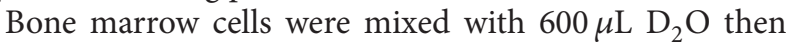
sonicated in an ice bath for $1 \mathrm{~min}$. Samples were centrifuged for $10 \mathrm{~min}$ at $4^{\circ} \mathrm{C}$ at $5000 \mathrm{~g}$, and the supernatants were transferred to NMR tubes.

For liver samples the organ extraction method used here, which derives from the Folch procedure [23], was adapted from the method described by Waters et al. [24]. Samples of liver tissue $(\sim 100 \mathrm{mg})$ were homogenized with a Polytron PT 2100 in $2 \mathrm{~mL}$ acetonitrile/ $\mathrm{H}_{2} \mathrm{O}(50 / 50, \mathrm{v} / \mathrm{v})$ containing $0.1 \%$ butylated hydroxytoluene (BHT) in an ice-water bath. The homogenates were centrifuged for $10 \mathrm{~min}$ at $4^{\circ} \mathrm{C}$ at $5000 \mathrm{~g}$, and the supernatants were removed and lyophilised. The resulting powders were reconstituted in $600 \mu \mathrm{L}$ of deuterium oxide $\left(\mathrm{D}_{2} \mathrm{O}\right)$. The reconstituted solutions were transferred to NMR tubes.

2.4.2. ${ }^{1}$ H Nuclear Magnetic Resonance (NMR) Analyses. All ${ }^{1} \mathrm{H}$ NMR spectra were obtained on a Bruker DRX-600 Avance NMR spectrometer operating at $600.13 \mathrm{MHz}$ for ${ }^{1} \mathrm{H}$ resonance frequency using an inverse detection $5 \mathrm{~mm}{ }^{1} \mathrm{H}-{ }^{13} \mathrm{C}$ -

${ }^{15} \mathrm{~N}$ cryoprobe attached to a CryoPlatform (the preamplifier cooling unit). 
The ${ }^{1} \mathrm{H}$ NMR spectra of plasma and bone marrow samples were acquired at $300 \mathrm{~K}$ using the Carr-Purcell-MeiboomGill (CPMG) spin-echo pulse sequence with presaturation with a total spin-echo delay $(2 \mathrm{n} \tau)$ of $40 \mathrm{~ms}$ to attenuate broad signals from proteins and lipoproteins. A total of 128 transients were acquired in $32 \mathrm{~K}$ data points using a spectral width of $12 \mathrm{ppm}$ and an acquisition time of $2.28 \mathrm{~s}$. Prior to Fourier transformation, an exponential line broadening function of $0.3 \mathrm{~Hz}$ was applied to the FID.

The ${ }^{1} \mathrm{H}$ NMR spectra of liver extracts were acquired at $300 \mathrm{~K}$ using the standard ${ }^{1} \mathrm{H}$ pulse sequence, accumulating 128 free induction decays into $32 \mathrm{~K}$ data points with a relaxation delay of $2 \mathrm{~s}$. A $12 \mathrm{ppm}$ spectral width was used. The data were apodized with an exponential function using a line broadening of $0.3 \mathrm{~Hz}$ prior to Fourier transformation. To confirm the chemical structure of the metabolites of interest, $2 \mathrm{D}^{1} \mathrm{H}-{ }^{1} \mathrm{H}$ COSY (Correlation Spectroscopy) and 2D ${ }^{1} \mathrm{H}_{-}{ }^{13} \mathrm{C}$ HSQC (Heteronuclear Single Quantum Coherence Spectroscopy) NMR experiments were performed on selected samples. For the ${ }^{1} \mathrm{H}-\mathrm{H}$ COSY NMR experiment, a total of 32 transients were acquired in 4096 data points. A total of 256 increments were measured in F1 using a spectral width of $10 \mathrm{ppm}$ and an acquisition time of $0.28 \mathrm{~s}$. The data were weighted using a sine-bell function in $t_{1}$ and $t_{2}$ prior to Fourier transformation (FT). ${ }^{1} \mathrm{H}^{13}{ }^{13} \mathrm{C}$ HSQC NMR spectra were collected in selected samples with ${ }^{1} \mathrm{H}$ detection. A relaxation delay of $2.5 \mathrm{~s}$ was used between pulses, with a refocusing delay equal to $1 / 4^{1} J_{\mathrm{C}-\mathrm{H}}(1.78 \mathrm{~ms})$. A total of 2048 data points with 64 scans per increment and 512 experiments were acquired with spectral widths of $10 \mathrm{ppm}$ in F2 and $180 \mathrm{ppm}$ in F1. The data were multiplied by a shifted Qsinebell function prior to FT.

Spectral assignment was based on matching 1D and 2D data to reference spectra in a home-made reference database, as well as with other databases (http://www.bmrb.wisc.edu/ and http://www.hmdb.ca/), and reports in the literature.

2.4.3. Data Reduction and Multivariate Statistical Analyses. All NMR spectra were phased and the baseline corrected. The data was then reduced using AMIX (version 3.8, Bruker, Analytik) to integrate $0.04 \mathrm{ppm}$ wide regions corresponding to the $\delta 10.0-0.5 \mathrm{ppm}$ region. The $\delta 5.1-4.5 \mathrm{ppm}$ region, which includes the water resonance, was excluded. To account for differences in sample amounts, each integrated region was normalized to the total spectral area. Multidimensional statistical analyses of NMR data were performed using Simca-P11 software (Umetrics, Umeå, Sweden). Principal components analysis (PCA) was applied to the paretoscaled spectral data to reveal treatment-related patterns. Projection to latent structure discriminant analysis (PLSDA) was also performed to improve the classification of the different groups of mice. Dummy variables, containing 0 and 1 , were created to describe the class membership of each observation. The number of components in the PLS models was chosen by cross-validation (7-fold). The parameters $R^{2}$ and $Q^{2}$ were used as measures for the robustness of a pattern recognition model. $R^{2}$ is the fraction of variance explained by a component, and cross-validation of $R^{2}$ gives $Q^{2}$ which reveals the fraction of the total variation predicted by a component; it is a measure of the difference between two (or more) groups. Typically a robust model has $R^{2}>50 \%$ and $Q^{2}>0.4$.

In addition, the statistical significance and validity of the PLS-DA results were assessed using a permutation test. This test can determine whether the specific classification of individuals in the designated groups is significantly better than any other random classification in two arbitrary groups [25]. In this procedure, the $Y$ matrix (group membership) is randomly permuted a number of times (200 times in this study), while the $X$ matrix (NMR buckets) is kept unchanged. For each "permuted" sample, a PLS-DA model is constructed, the $R^{2} / Q^{2}$ values calculated and compared to the values of the "original" model. As a result of this test, $R^{2}$ and $Q^{2}$ values of the "original" model (on the right of biplot) and the "permuted" models are displayed versus the correlation between the "original" $Y$ matrix and the "permuted" $Y$ matrix. A regression line is estimated from this biplot. Valid models correspond to a negative $Q^{2}$ intercept of the regression line.

Data were preprocessed using Orthogonal Signal Correction (OSC) with the treatment as a correction factor. The OSC filtering [26] was applied to remove variation not linked to the treatment (confounding factors such as physiological, experimental, or instrumental variation).

The identification of major metabolic perturbations within the pattern recognition models was achieved by analysis of corresponding loading plots and variable importance in the projection (VIP). VIP, a global indicator measuring the influence of each variable on the PLS components, was used to derive a subset of the most important variables for the separation of experimental groups. An arbitrary threshold of VIP $>1.0$ was chosen to select the variables.

Imported data were mean centered and Pareto scaled for all PLS analyses.

Univariate statistical tests using $R$ software were also carried out on the bucket integrated NMR spectra, comparing endosulfan-treated to control mice for bone marrow, plasma and liver samples. Each bucket was treated as an independent variable. Statistically significant changes between the distributions of treated animals and the control group were assessed using a parametric Student's $t$-test as well as the nonparametric Kruskal-Wallis test. A value of $P<0.05$ was considered significant. The software $R$ and the packages used in this work were downloaded freely from the website (http://www.r-project.org/).

\section{Results}

Throughout our investigation we found no difference in body weight between endosulfan-treated and control groups, and there was no difference in the weight of the liver, or brain between the groups (data not shown). However a slight but significant decrease was observed in kidney in females. 


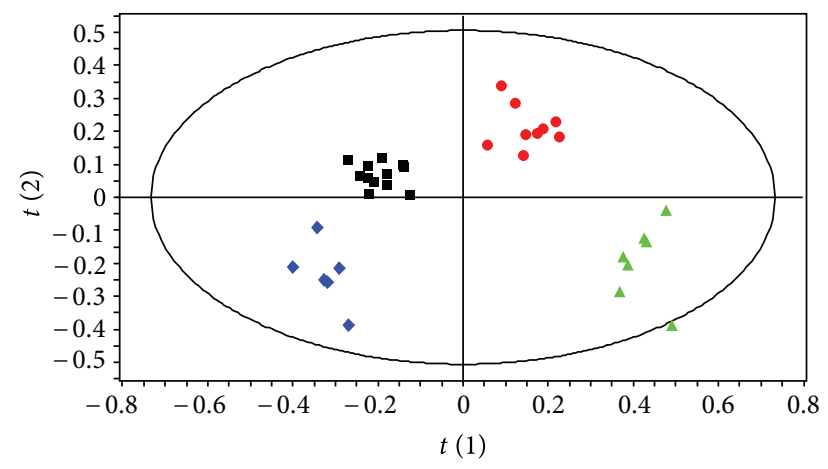

FIgURE 1: PLS-DA score plot based on the ${ }^{1}$ H NMR spectra of plasma samples from nonexposed males(green triangle, $n=7$ ), exposed male (red circle, $n=9$ ), nonexposed females (blue diamond, $n=6$ ), and exposed female mice (black square, $n=12$ ) $\left(Q^{2}=0.60, R^{2}=72.7 \%\right.$, and $\mathrm{A}=3$ (Latent Variables fitted)).

To identify the metabolic fingerprint characterizing dietary exposure to endosulfan at low doses, high-resolution ${ }^{1}$ H NMR spectra were recorded from samples of bone marrow, plasma, and liver of control and endosulfan-treated 14-week-old mice. Thirty-one metabolites were identified, and Table 1 lists the compounds assigned based on their $1 \mathrm{D}$ and 2D spectra. From these results, PLS-DA analysis of each tissue was carried out as described in the materials and methods section; this highlighted the different effects of treatment between male and female mice. Since the metabolic profiles of each gender are quite distinct, female and male mice were considered independently in order to identify the metabolic changes resulting from endosulfan treatment. Intercept values of permutation test, showing the robustness of the models, are presented in Table 2 for PLS-DA models per sex. All metabolic changes are summarized in Table 3.

\subsection{Metabolic Profiles of Plasma from Endosulfan-Treated}

Mice. Pattern recognition of the ${ }^{1} \mathrm{H}$ NMR spectra from plasma of mice exposed to dietary endosulfan is shown in Figure 1. The PLS-DA score plots clearly distinguish samples of exposed mice from those of nonexposed mice along PLSDA component 2. Animal gender is also separated along PLSDA component 1. PLS-DA models were built to model the differences between endosulfan-exposed males separately to those of females (Figures 2(a) and 2(c)). These models were robust and predictable $\left(R^{2}=0.989\right.$ and $Q^{2}=0.95$ for females and $R^{2}=0.976$ and $Q^{2}=0.83$ for males). Permutation tests showed that the model was not overfitted (Table 2). Loading plots in Figures 2(b) and 2(d) show discriminant metabolites in treated and untreated animals, in females and males, respectively. Discriminant metabolites were summarized in Table 3. Dietary exposure of female mice to endosulfan led to a decrease in plasma LDL and/or VLDL. Biochemical analysis of female plasma confirmed the decrease in LDL level (data not shown). Dietary exposure of females to endosulfan also led to a significant decrease in choline levels and a clear increase in glucose levels. The categories of metabolites identified in plasma samples from exposed male mice were different to those of female mice except the change in glucose levels which were also observed in both genders. Lactate levels were increased in males exposed to endosulfan but no changes in choline or VLDL and/or LDL levels were observed.

\subsection{Metabolic Profiles of Bone Marrow from Endosulfan-} Treated Mice. The PLS-DA model, described in the materials and methods section, separated all four groups of bone marrow samples as shown in Figure $3\left(R^{2}=0.975\right.$ and $\left.Q^{2}=0.94\right)$. Bone marrow from endosulfan-exposed and nonexposed mice appear as distinct metabolic groups along PLS-DA component 1 , whereas animal gender appears separately along PLS-DA component 2 . To further clarify the impact of treatment in the sample groups of each gender, other PLSDA models were built, and the results modelled separately for male and female sample groups as shown in Figures 4(a) and 4(c). For both gender groups the ${ }^{1} \mathrm{H}$ NMR profiles derived from endosulfan-treated mouse samples were distinguished from those of the controls using PLS-DA analysis. These models were robust and predictable $\left(R^{2}=0.996\right.$ and $Q^{2}=0.92$ for females and $R^{2}=0.995$ and $Q^{2}=0.97$ for males). Permutation tests showed that the model was not overfitted (Table 2). Loading plots in Figures 4(b) and 4(d) show discriminant metabolites in treated and untreated animals in females and males, respectively. Discriminant metabolites were summarized in Table 3. For both female and male mice dietary exposure to endosulfan resulted in a decrease in fatty acids in bone marrow, characterized by the long chain lipid $\left(\mathrm{CH}_{2}\right)_{n}$ signal and by an increase in valine and isoleucine. Gender differences were clearly observed: in treated females the levels of lysine, alanine, succinate, and glutamate/glutamine were increased; in contrast male mice had increased levels of acetate, tyrosine, and inosine upon exposure to endosulfan whereas the level of lactate and ATP/ADP/AMP decreased. The level of choline compounds was shown to be increased in females and decreased in males.

3.3. Metabolic Profiles of Aqueous Liver Extracts from Endosulfan-Treated Mice. The PLS-DA score plots of liver samples clearly separated exposed mice from nonexposed mice along PLS-DA component 1 (Figure 5). Gender was separated along PLS-DA component 2. For the control group, the distinction between male and female mice was not clear. PLS-DA models were then built to model the differences between exposed males and females separately (Figures 6(a) and $6(\mathrm{c}))$. These models were robust and predictable $\left(R^{2}=\right.$ 0.984 and $Q^{2}=0.965$ for females and $R^{2}=0.991$ and $Q^{2}=$ 0.93 for males). Permutation tests showed that the model was not overfitted (Table 2). Loading plots in Figures 6(b) and 6(d) show discriminant metabolites in treated and untreated animals, in females and males respectively. Discriminant metabolites were summarized in Table 3. In males and females, hepatic metabolic disturbances were characterized by a net decrease-oxidized glutathione concomitantly with an increase of taurine and betaine levels, suggesting a perturbation of oxidative status upon endosulfan exposure. In females glucose levels were decreased whereas lactate levels 
TABLE 1: ${ }^{1} \mathrm{H}$ and ${ }^{13} \mathrm{C}$ resonance assignments with chemical shifts, multiplicity, and $J$-couplings for signals identified in plasma, bone marrow, and liver in mice.

\begin{tabular}{|c|c|c|}
\hline Compound & $\delta_{\mathrm{H}} \mathrm{ppm}$ (multiplicity, coupling constant, assignment) $/ \delta_{\mathrm{C}} \mathrm{ppm}$ & Biological matrice \\
\hline Acetate & $1.92\left(\mathrm{~s}, \mathrm{CH}_{3}\right) / 25.9$ & Liver, bone marrow \\
\hline Alanine & $1.48\left(\mathrm{~d}, J=7.1 \mathrm{~Hz}, \mathrm{CH}_{3}\right) / 18.9 ; 3.78(\mathrm{q}, J=7.2 \mathrm{~Hz}, \mathrm{CH}) / 53.1$ & Liver, plasma \\
\hline ATP/ADP/AMP & $\begin{array}{l}4.51\left(\mathrm{~m}, \mathrm{CH}_{2}\right) / 73.3 ; 6.15(\mathrm{~d}, J=5.9 \mathrm{~Hz}, \mathrm{CH}) / 89.5 ; 8.27(\mathrm{~s}, \mathrm{CH}, \text { ring }) / 155.2 ; 8.58(\mathrm{~s}, \mathrm{CH} \text {, } \\
\text { ring }) / 142.6\end{array}$ & Liver, bone marrow \\
\hline Betaine & $3.27\left(\mathrm{~s}, \mathrm{CH}_{3}\right) / 56.1 ; 3.91\left(\mathrm{~s}, \mathrm{CH}_{2}\right) / 68.9$ & Liver \\
\hline Choline & $3.22\left(\mathrm{~s}, \mathrm{~N}\left(\mathrm{CH}_{3}\right)_{3}\right) / 56.9 ; 3.52\left(\mathrm{~m}, \mathrm{NCH}_{2}\right) / 70.0 ; 4.05\left(\mathrm{~m}, \mathrm{CH}_{2}\right) / 58.3$ & $\begin{array}{l}\text { Liver, plasma, bone } \\
\text { marrow }\end{array}$ \\
\hline Citrate & $2.54(\mathrm{~d}, J=15 \mathrm{~Hz}, 2 \mathrm{CH}) / 48.7 ; 2.70(\mathrm{~d}, J=15 \mathrm{~Hz}, 2 \mathrm{CH}) / 48.7$ & Plasma, bone marrow \\
\hline Creatine & $3.93\left(\mathrm{~s}, \mathrm{CH}_{2}\right) / 56.4 ; 3.03\left(\mathrm{~s}, \mathrm{CH}_{3}\right) / 39.9$ & $\begin{array}{l}\text { Liver, plasma, bone } \\
\text { marrow }\end{array}$ \\
\hline$\alpha$-Glucose & $\begin{array}{l}3.41(\mathrm{~m}, \mathrm{CH}) / 72.3 ; 3.54(\mathrm{~m}, \mathrm{CH}) / 73.9 ; 3.71(\mathrm{~m}, \mathrm{CH}) / 75.4 ; 3.83(\mathrm{~m}, \mathrm{CH}) / 74.2 ; 3.84(\mathrm{~m}, \\
\mathrm{CH}) / 63.3 ; 5.23(\mathrm{~d}, \mathrm{CH}, J=3.8 \mathrm{~Hz}) / 94.8\end{array}$ & Liver, plasma \\
\hline$\beta$-Glucose & $\begin{array}{l}3.25(\mathrm{~m}, \mathrm{CH}) / 76.9 ; 3.41(\mathrm{~m}, \mathrm{CH}) / 72.3 ; 3.48(\mathrm{~m}, \mathrm{CH}) / 78.4 ; 3.73(\mathrm{~m}, \mathrm{CH}) / 63.3 ; 3.90(\mathrm{~m}, \\
\mathrm{CH}) / 63.4 ; 4.64(\mathrm{~d}, \mathrm{CH}, J=8 \mathrm{~Hz}) / 98.6\end{array}$ & Liver, plasma \\
\hline Glutamate & $2.06\left(\mathrm{~m}, \mathrm{CH}_{2}\right) / 29.6 ; 2.36\left(\mathrm{~m}, \mathrm{CH}_{2}\right) / 36.1 ; 3.78(\mathrm{~m}, \mathrm{CH}) / 56.7$ & Liver, bone marrow \\
\hline Glutamine & $2.16\left(\mathrm{~m}, \mathrm{CH}_{2}\right) / 29.1 ; 2.46\left(\mathrm{~m}, \mathrm{CH}_{2}\right) / 33.6 ; 3.78(\mathrm{~m}, \mathrm{CH}) / 56.7$ & $\begin{array}{l}\text { Liver, plasma, bone } \\
\text { marrow }\end{array}$ \\
\hline Glutathione (oxidized) & $\begin{array}{l}2.18\left(\mathrm{~m}, \mathrm{CH}_{2}\right) / 29.1 ; 2.55\left(\mathrm{~m}, \mathrm{CH}_{2}\right) / 34.2 ; 2.98(\mathrm{~m}, \mathrm{CH}) / 41.7 ; 3.31(\mathrm{~m}, \mathrm{CH}) / 41.6 ; 3.78(\mathrm{~m}, \\
\left.\mathrm{CH}_{2}\right) / 46.2 ; 3.78(\mathrm{~m}, \mathrm{CH}) / 56.7\end{array}$ & Liver, bone marrow \\
\hline Glycerophosphocholine & $3.22\left(\mathrm{~s}, \mathrm{~N}\left(\mathrm{CH}_{3}\right)_{3}\right) / 56.9 ; 3.68\left(\mathrm{~m}, \mathrm{NCH}_{2}\right) / 68.9 ; 4.33\left(\mathrm{~m}, \mathrm{CH}_{2}\right) / 62.1$ & $\begin{array}{l}\text { Liver, plasma, bone } \\
\text { marrow }\end{array}$ \\
\hline Glycine & $3.56\left(\mathrm{~s}, \mathrm{CH}_{2}\right) / 44.3$ & $\begin{array}{l}\text { Liver, plasma, bone } \\
\text { marrow }\end{array}$ \\
\hline Glycogen & $3.66(\mathrm{~m}, \mathrm{CH}) / 79.3 ; 3.98(\mathrm{~m}, \mathrm{CH}) / 75.8 ; 5.41(\mathrm{~m}, \mathrm{CH}) / 102.2$ & Liver \\
\hline Inosine & $\begin{array}{l}4.28(\mathrm{~m}, \mathrm{CH}) / 88.2 ; 4.44(\mathrm{~m}, \mathrm{CH}) / 73.1 ; 6.11(\mathrm{~d}, J=5.7 \mathrm{~Hz}, \mathrm{CH} \text { ring }) / 90.9 ; 8.23(\mathrm{~s}, \mathrm{CH} \\
\text { ring }) / 148.9 ; 8.32(\mathrm{~s}, \mathrm{CH} \text { ring }) / 142.7\end{array}$ & Liver \\
\hline Isoleucine & $0.93\left(\mathrm{t}, J=7.2 \mathrm{~Hz}, \mathrm{CH}_{3}\right) / 13.9 ; 0.99\left(\mathrm{~d}, J=7.2 \mathrm{~Hz}, \mathrm{CH}_{3}\right) / 17.4$ & Liver, plasma \\
\hline Lactate & $1.33\left(\mathrm{~d}, J=7.2 \mathrm{~Hz}, \mathrm{CH}_{3}\right) / 22.9 ; 4.11(\mathrm{q}, J=7.2 \mathrm{~Hz}, \mathrm{CH}) / 71.2$ & $\begin{array}{l}\text { Liver, plasma, bone } \\
\text { marrow }\end{array}$ \\
\hline Leucine & $\begin{array}{l}0.94\left(\mathrm{~d}, J=6 \mathrm{~Hz}, \mathrm{CH}_{3}\right) / 23.6 ; 0.97\left(\mathrm{~d}, J=6 \mathrm{~Hz}, \mathrm{CH}_{3}\right) / 24.7 ; 1.71(\mathrm{~m}, \mathrm{CH}) / 27.3 ; 1.71(\mathrm{~m}, \\
\left.\mathrm{CH}_{2}\right) / 42.6\end{array}$ & Liver, plasma \\
\hline Lipids & $0.88\left(\mathrm{~m}, \mathrm{CH}_{3}\right) ; 1.30\left(\mathrm{~m},\left(\mathrm{CH}_{2}\right)_{\mathrm{n}}\right) ; 1.40\left(\mathrm{~m}, \mathrm{CH}_{2}\right) ; 5.30(\mathrm{~m}, \mathrm{CH}=\mathrm{CH})$ & Plasma, bone marrow \\
\hline Lipids (LDL, VLDL) & $0.87\left(\mathrm{~m}, \mathrm{CH}_{3}\right) / 14.7 ; 1.28\left(\mathrm{~m}, \mathrm{CH}_{2}\right) / 34.6$ & Plasma \\
\hline Lysine & $1.48\left(\mathrm{~m}, \mathrm{CH}_{2}\right) / 24.6 ; 1.72\left(\mathrm{~m}, \mathrm{CH}_{2}\right) / 29.1 ; 1.91\left(\mathrm{~m}, \mathrm{CH}_{2}\right) / 32.7 ; 3.01\left(\mathrm{~m}, \mathrm{CH}_{2}\right) / 42.1$ & $\begin{array}{l}\text { Liver, plasma, bone } \\
\text { marrow }\end{array}$ \\
\hline Methionine & $2.12\left(\mathrm{~s}, \mathrm{CH}_{3}\right) ; 2.18\left(\mathrm{~m}, \mathrm{CH}_{2}\right) ; 2.64\left(\mathrm{t}, J=7.2 \mathrm{~Hz}, \mathrm{CH}_{2}\right)$ & Plasma \\
\hline Nicotinic acid & $\begin{array}{l}7.60(\mathrm{dd}, J=7.9 \text { and } 5 \mathrm{~Hz}, \mathrm{CH} \text { ring); } 8.25(\mathrm{~m}, \mathrm{CH} \text { ring); } 8.58(\mathrm{~m}, \mathrm{CH} \text { ring); } 8.92 \text { (s, CH } \\
\text { ring) }\end{array}$ & Liver \\
\hline Phenylalanine & $7.43(\mathrm{t}, J=7 \mathrm{~Hz}, \mathrm{CH}$ ring); $7.38(\mathrm{t}, J=7 \mathrm{~Hz}, \mathrm{CH}$ ring); $7.32(\mathrm{~d}, J=7 \mathrm{~Hz}, \mathrm{CH}$ ring $)$ & $\begin{array}{l}\text { Liver, plasma, bone } \\
\text { marrow }\end{array}$ \\
\hline Phosphorylcholine & $3.22\left(\mathrm{~s}, \mathrm{~N}\left(\mathrm{CH}_{3}\right)_{3}\right) / 56.9 ; 3.60\left(\mathrm{~m}, \mathrm{CH}_{2}\right) / 69.4 ; 4.18\left(\mathrm{~m}, \mathrm{CH}_{2}\right) / 60.7$ & $\begin{array}{l}\text { Liver, plasma, bone } \\
\text { marrow }\end{array}$ \\
\hline Succinate & $2.41(\mathrm{~s}) / 36.8$ & Liver \\
\hline Taurine & $3.26\left(\mathrm{t}, J=7.3 \mathrm{~Hz}, \mathrm{CH}_{2}\right) / 49.9 ; 3.43\left(\mathrm{t}, J=7.3 \mathrm{~Hz}, \mathrm{CH}_{2}\right) / 38.1$ & $\begin{array}{l}\text { Liver, plasma, bone } \\
\text { marrow }\end{array}$ \\
\hline Tyrosine & 6.90 (m, CH ring); 7.18 (m, CH ring) & $\begin{array}{l}\text { Liver, plasma, bone } \\
\text { marrow }\end{array}$ \\
\hline Uridine & $\begin{array}{l}4.14(\mathrm{~m}, \mathrm{CH}) / 86.9 ; 4.38(\mathrm{~m}, \mathrm{CH}) / 76.4 ; 5.88(\mathrm{~m}, \mathrm{CH} \text { ring }) / 104.9 ; 5.90(\mathrm{~m}, \mathrm{CH}) / 92.1 ; 7.88 \\
(\mathrm{~d}, J=8.10 \mathrm{~Hz}, \mathrm{CH} \text { ring }) / 144.5 ;\end{array}$ & Liver \\
\hline Valine & $0.99\left(\mathrm{~d}, J=7 \mathrm{~Hz}, \mathrm{CH}_{3}\right) / 19.5 ; 1.05\left(\mathrm{~d}, J=7 \mathrm{~Hz}, \mathrm{CH}_{3}\right) / 20.7 ; 2.28(\mathrm{~m}, \mathrm{CH}) / 31.9$ & Liver, plasma \\
\hline
\end{tabular}




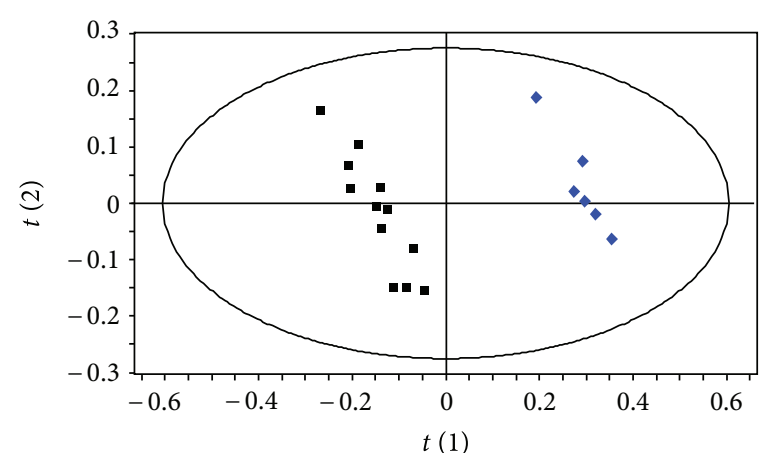

(a)

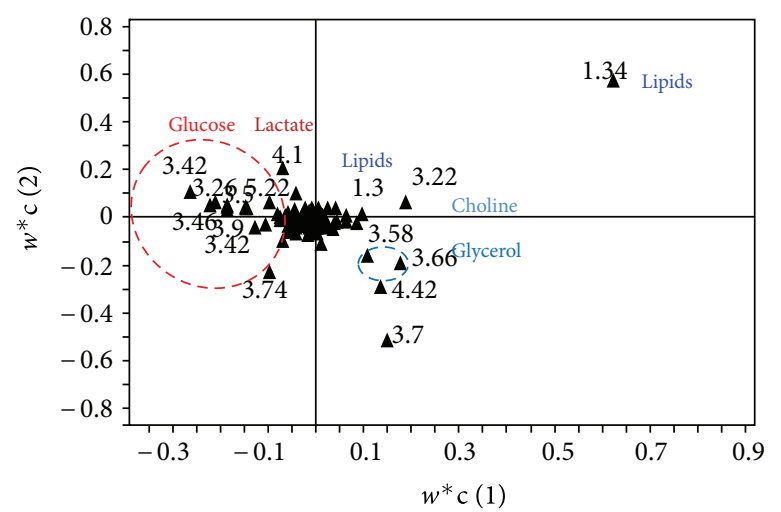

(b)

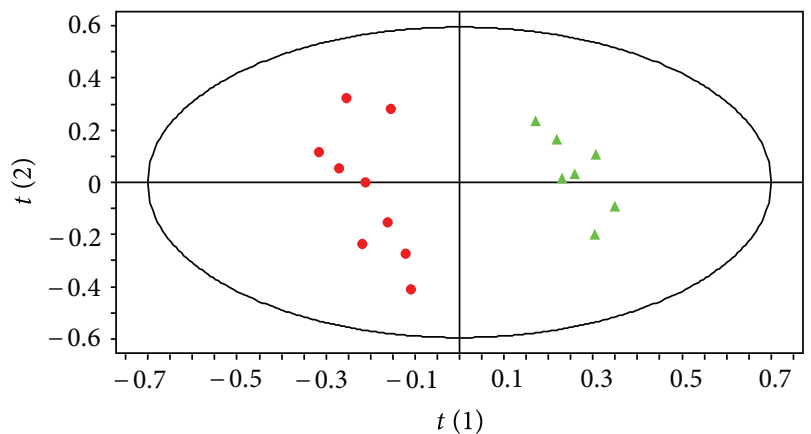

(c)

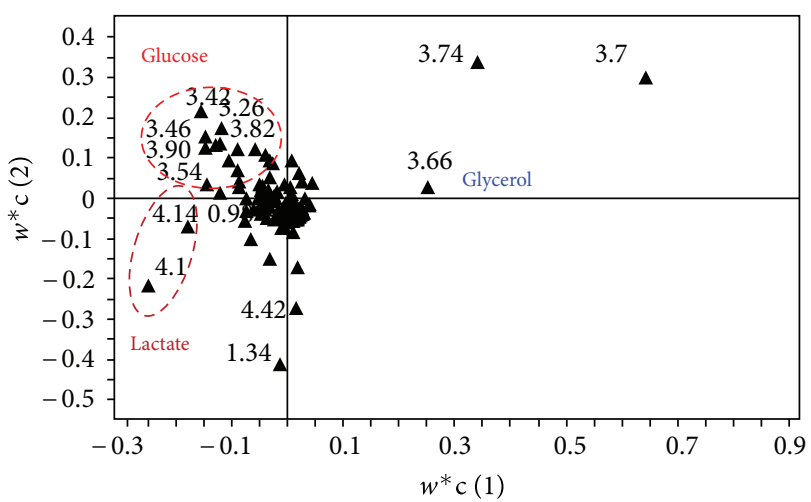

(d)

Figure 2: PLS-DA (a) score plot and (b) loading plot based on the ${ }^{1} \mathrm{H}$ NMR spectra of plasma samples from nonexposed (blue diamond, $n=6)$ and exposed female mice (black square, $n=12)\left(Q^{2}=0.95, R^{2}=98.9 \%\right.$, and A $=2$ ). PLS-DA (c) score plot and (d) loading plot based on the ${ }^{1} \mathrm{H}$ NMR spectra of plasma samples from nonexposed (green triangle, $\left.n=7\right)$ and exposed males $($ red circle, $n=9)\left(Q^{2}=0.83\right.$, $R^{2}=97.6 \%$, and $\mathrm{A}=3$ ).

TABLE 2: Intercept values $\left(R^{2} / Q^{2}\right)$ of permutation test for the PLS-DA models.

\begin{tabular}{lcccccrrr}
\hline & \multicolumn{3}{c}{ Female } & \multicolumn{2}{c}{ Male } & \multicolumn{2}{c}{ Nonexposed } & \multicolumn{2}{c}{ Exposed } \\
& $R^{2}$ & $Q^{2}$ & $R^{2}$ & $Q^{2}$ & $R^{2}$ & $Q^{2}$ & $Q^{2}$ \\
\hline Plasma & 0.401 & -0.303 & 0.402 & -0.301 & 0.505 & -0.406 & 0.508 & -0.411 \\
Bone marrow & 0.581 & -0.322 & 0.585 & -0.352 & 0.912 & -0.205 & 0.908 & -0.158 \\
Liver & 0.077 & -0.307 & 0.084 & -0.316 & 0.181 & -0.350 & 0.185 & -0.346 \\
\hline
\end{tabular}

The intercept values $\left(R^{2} / Q^{2}\right)$ represent the values of $R^{2}$ and $Q^{2}$ of a purely random model. $R^{2}$ intercept $<0.3$ and $Q^{2}$ intercept $<0.05$ indicate a robust model.

were increased. By contrast in male mice dietary exposed to endosulfan, no changes were observed in glucose level whereas lactate level was decreased. In addition, in male mice, 5 metabolites were found to distinguish from females: alanine, glutamate/glutamine, and glycogen whose levels decreased, and choline whose level increased.

\section{Discussion}

Endosulfan is an organochlorine pesticide which was banned in France in 2006. However, recent EFSA reports have shown that residues of this compound are still found in some fruits and vegetables in the European Union [3]. In addition, due to its capacity to bioaccumulate, endosulfan is still found in human biological fluids and tissues. Subchronic exposure to this contaminant commonly affects the central nervous system [15, 27], immune [28], and reproductive systems [29]. These effects have been at least partly linked to an increase in oxidative stress [30-32]. Occupational exposure to pesticides is often linked to an increased risk of developing certain pathologies in adults and children [1, 33]. The general population is also exposed to pesticides mainly through the presence of contaminants in food, where consumers are exposed to low doses of pesticides alone or in mixtures throughout their life. Although consumer exposure is different from occupational exposure in mode, quantity, duration, frequency, and so forth, improved knowledge of the influence of such exposure on health is needed. Moreover, since exposure of the general population to pesticides cannot 
TABLE 3: Summary of the relative metabolite changes in plasma, bone marrow, and liver upon long term dietary exposure of mice to low doses of endosulfan.

\begin{tabular}{|c|c|c|c|c|c|c|c|}
\hline \multirow{2}{*}{ Major metabolites } & \multirow{2}{*}{ Discriminant NMR buckets } & \multicolumn{2}{|c|}{ Bone marrow } & \multicolumn{2}{|c|}{ Plasma } & \multicolumn{2}{|c|}{ Liver } \\
\hline & & Female & Male & Female & Male & Female & Male \\
\hline Lipids VLDL/LDL & $1.26 ; 1.30 ; 1.34 ; 1.38$ & & & $\searrow^{* *}$ & & & \\
\hline Lipids & $0.90 ; 1.30 ; 1.34$ & $\searrow^{* * *}$ & $\searrow^{*}$ & & & & \\
\hline Unsaturated lipids & 5.34 & $\searrow^{* * *}$ & & & & & \\
\hline Lactate & $1.34 ; 4.10$ & & $\searrow^{*}$ & & $\nearrow^{*}$ & $\nearrow^{* *}$ & $\searrow^{* *}$ \\
\hline Choline/PCho/GPCho & $3.18 ; 3.22 ; 4.02 ; 4.22 ; 4.30$ & $\nearrow^{* *}$ & $\searrow^{*}$ & $\searrow^{*}$ & & & $\nearrow^{*}$ \\
\hline Glucose & $\begin{array}{c}3.26 ; 3.38 ; 3.42 ; 3.46 ; 3.50 ; 3.54 \\
3.82 ; 3.90 ; 5.22\end{array}$ & & & $\nearrow^{* * *}$ & $\nearrow^{*}$ & $\searrow^{* * *}$ & \\
\hline Glycogen & 5.40 & & & & & & $\searrow^{*}$ \\
\hline Lysine & $1.66 ; 1.70 ; 1.74 ; 3.02$ & $\nearrow^{* *}$ & & & & & \\
\hline Valine & 0.98 & $\nearrow^{*}$ & $\nearrow^{*}$ & & & & \\
\hline Isoleucine & 0.94 & $\nearrow^{* *}$ & $\nearrow^{*}$ & & $\nearrow^{*}$ & & \\
\hline Alanine & $1.46 ; 1.50$ & $\nearrow^{* *}$ & & & & & $\searrow^{* * *}$ \\
\hline Glutamate/glutamine & $2.10 ; 2.14 ; 2.34 ; 2.38 ; 2.46$ & $\nearrow^{* *}$ & & & & & $\searrow^{* * *}$ \\
\hline $\begin{array}{l}\text { Glutathione } \\
\text { (oxidized) }\end{array}$ & $2.18 ; 2.54 ; 2.58 ; 3.78$ & & & & & $\searrow^{*}$ & $\searrow^{* * *}$ \\
\hline Betaine & 3.26 & & & & & $\nearrow^{* * *}$ & $\nearrow^{* * *}$ \\
\hline Taurine & $3.26 ; 3.42$ & & & & & $\nearrow^{* * *}$ & $\nearrow^{* * *}$ \\
\hline Acetate & 1.94 & & $\nearrow^{*}$ & & & & \\
\hline Tyrosine & $6.90 ; 7.18 ; 7.22$ & & $\nearrow^{* *}$ & & & & \\
\hline Inosine & $6.06 ; 8.22$ & & $\nearrow^{* *}$ & & & & \\
\hline ATP/ADP/AMP & $4.42 ; 4.38 ; 6.14 ; 8.26 ; 8.58$ & & $\searrow^{* * *}$ & & & & \\
\hline Succinate & 2.42 & $\nearrow^{* *}$ & $\nearrow^{* *}$ & & & & \\
\hline Creatine & 3.94 & & $\nearrow^{*}$ & & & & \\
\hline
\end{tabular}

Comparisons among groups were performed by Kruskal-Wallis test. Changes are relative to control samples: \: decrease; $\nearrow$ : increase; ${ }^{* * *} P<0.001 ;{ }^{* *} P<$ $0.01 ;{ }^{*} P<0.05$ as compared with control.

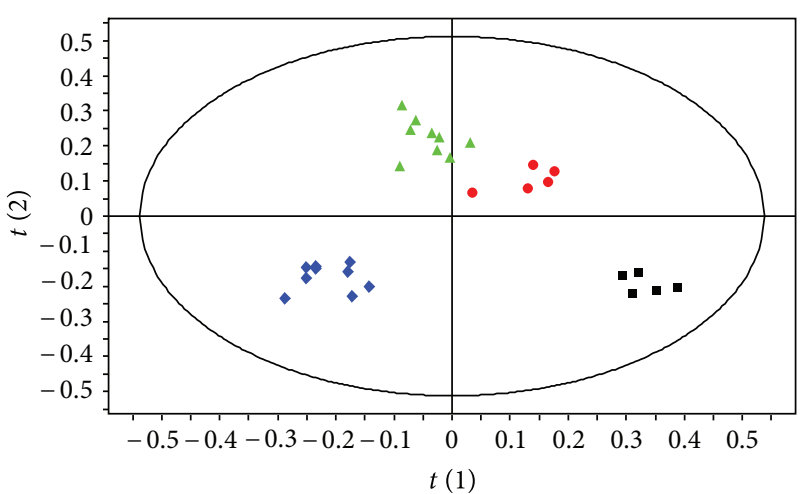

FIGURE 3: PLS-DA score plot based on the ${ }^{1}$ H NMR spectra of bone marrow samples from nonexposed male (green triangle, $n=7$ ), exposed male (red circle, $n=5$ ), nonexposed female (blue diamond, $n=9)$ and exposed female mice (black square, $n=5)\left(Q^{2}=0.94\right.$, $R^{2}=97.5 \%$, and $\left.\mathrm{A}=4\right)$.

be quantified, the development of approaches to enable identification of biological markers of exposure to these compounds is of great interest for epidemiological studies.
In this study, we investigated the metabolic fingerprint of a dietary exposure to low doses of endosulfan using an ${ }^{1} \mathrm{H}$ NMR-based metabonomic approach on bone marrow, liver, and plasma in male and female mice. Our results show that dietary exposure to endosulfan is characterized by specific metabolic fingerprints in plasma, liver, and bone marrow of mice exposed to dietary endosulfan. The PLS-DA models obtained in this study are valid and robust, as shown by cross-validated $Q^{2}$ values and $R^{2}$ and $Q^{2}$ intercept values of permutation test (Table 2). The main changes observed were an increase in plasma glucose in both gender, a decrease in LDL levels especially in females and biochemical changes to the membrane composition of bone marrow cells (lipids and choline/phosphocholine). The variations in taurine, betaine, and oxidized glutathione in both genders could be linked to a disturbance of oxidative status upon endosulfan exposure; glucose, lactate variations could be useful as biomarkers for liver function changes in both males and females. Some metabolic changes appear to be gender-specific (e.g., plasma lipids LDL and hepatic levels of lactate and glucose).

4.1. Endosulfan-Induced Disturbances in Energy Metabolism. Changes to the level of metabolites involved in energy 


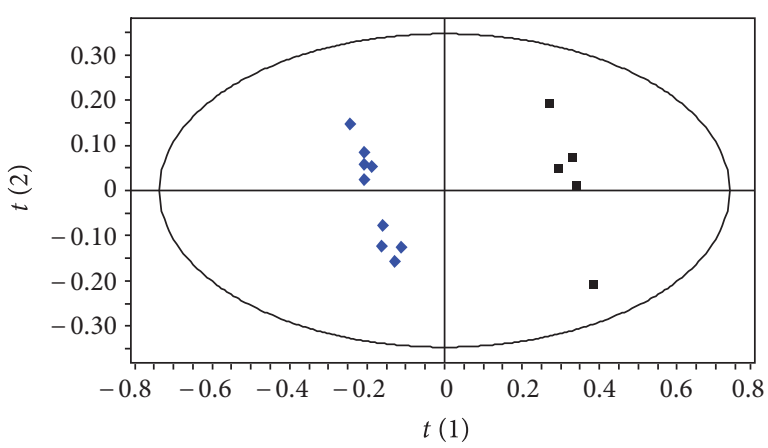

(a)

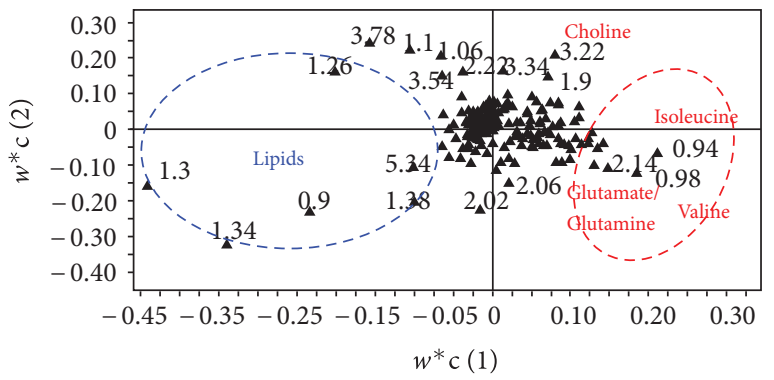

(b)

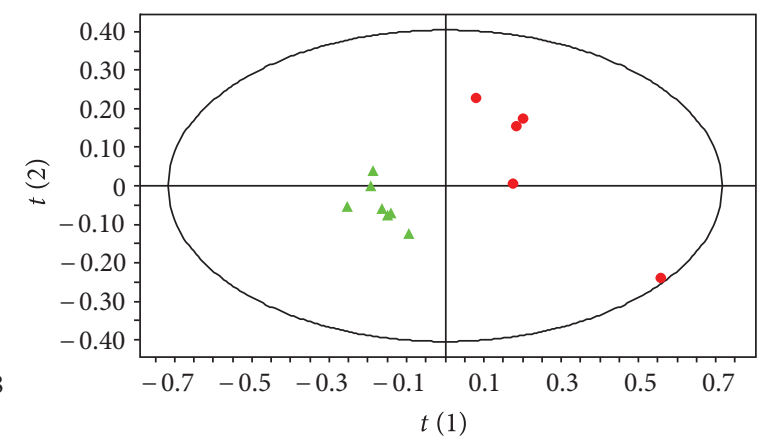

(c)

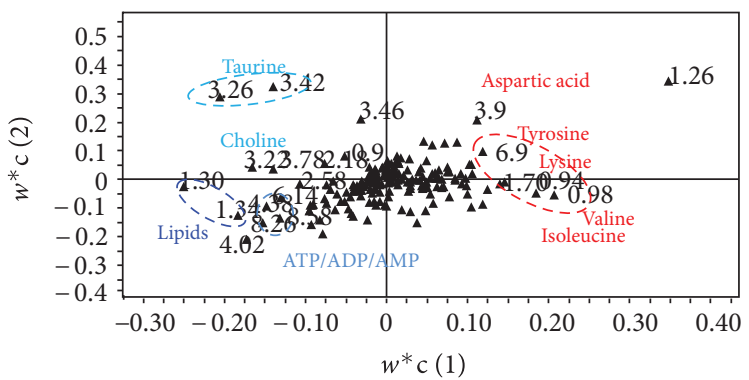

(d)

FIGURE 4: PLS-DA (a) score plot and (b) loading plot based on the ${ }^{1} \mathrm{H}$ NMR spectra of bone marrow samples from nonexposed (blue diamond, $n=9)$ and exposed female mice (black square, $n=5)\left(Q^{2}=0.92, R^{2}=99.6 \%\right.$, and A = 2). PLS-DA (c) score plot and (d) loading plot based on the ${ }^{1} \mathrm{H}$ NMR spectra of bone marrow samples from nonexposed (green triangle, $\left.n=7\right)$ or exposed male $($ red circle, $n=5)\left(Q^{2}=0.97\right.$, $R^{2}=99.5 \%$, and $\left.\mathrm{A}=4\right)$.

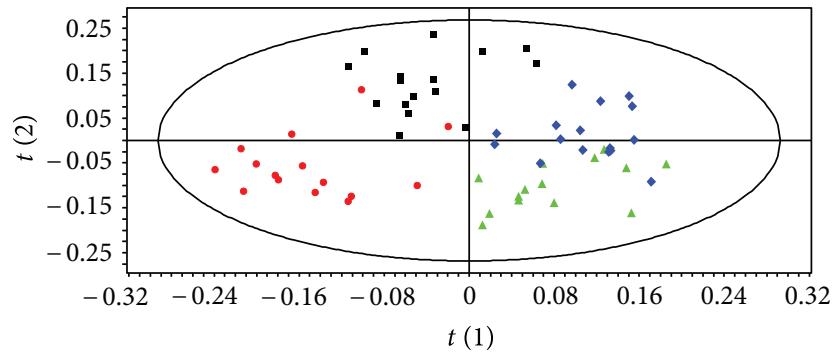

FIgURE 5: PLS-DA score plot based on the ${ }^{1} \mathrm{H}$ NMR spectra of aqueous liver extracts sampled from nonexposed male (green triangle, $n=14$ ), exposed male (red circle, $n=15$ ), nonexposed female (blue diamond, $n=16$ ) and exposed female mice (black square, $n=16)\left(Q^{2}=0.657, R^{2}=73.3 \%\right.$, and $\left.\mathrm{A}=3\right)$.

metabolism were observed upon dietary exposure to low doses of endosulfan during the pre- and postnatal period. Dietary exposure of female mice to endosulfan led to both an increase in plasma glycaemia and a decrease in endogenous hepatic glucose. The altered glucose levels could be related to the induction of the glycolytic pathway since a concomitant increase in liver lactate levels was also observed in females upon exposure. In contrast, in male mice the increase in plasma glucose levels appeared to be more associated with a decrease in activity of the hepatic glycolytic pathway, since lactate levels were decreased in the liver. Insulin insufficiency could also be causing the elevated blood glucose levels observed in exposed male and female mice. Indeed, endosulfan has already been shown to affect glucose levels in rat plasma and to have an impact on the $B$ cells of the pancreas that are responsible for insulin secretion [13,34]. Although it cannot be confirmed from the data presented here, our results are in agreement with dysfunctional insulin-mediated regulation of glucose utilisation by tissues. Moreover our data showed that, even at low doses, endosulfan caused changes to endogenous glucose content in the liver and plasma levels that could be linked to the onset of pathologies such as diabetes or insulin resistance. A physiological response to such hyperglycaemia could increase the consumption of glucose by muscle and fat tissue. This needs to be confirmed by further experiments. Our results are also in agreement with Lee et al., who observed that serum concentrations of OC pesticides are positively and significantly correlated with high fasting glucose in a population of nondiabetic human subjects [35].

Taurine levels in male mice were increased in liver upon endosulfan exposure. Taurine is an important metabolite involved in bile acid synthesis, osmoregulation, and intracellular calcium levels [36]. It is generally regarded as a sensitive marker indicating changes in liver metabolism. Furthermore, betaine levels were significantly increased in the liver of both genders. Betaine and taurine are important osmolytes and appeared to be critical for proper liver function [36]. Osmolytes have been shown to affect protein stability against a wide variety of adverse environmental conditions [37]. The increase of betaine or taurine could be linked to hepatic 


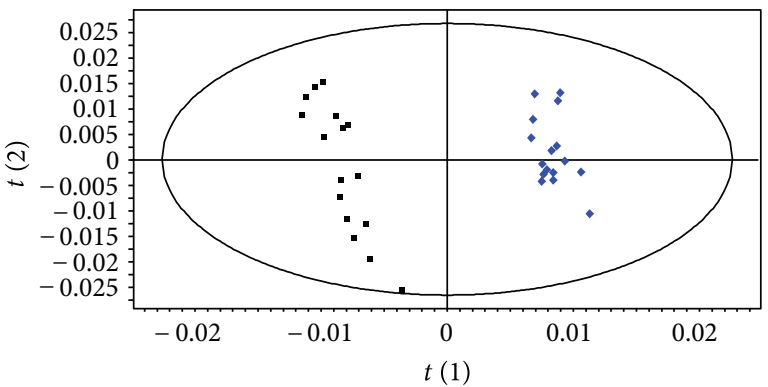

(a)

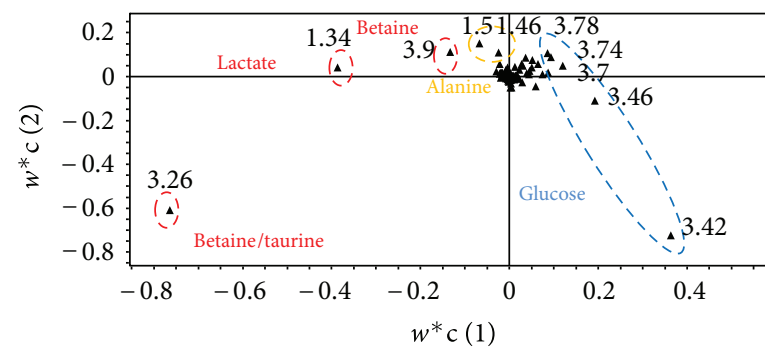

(b)

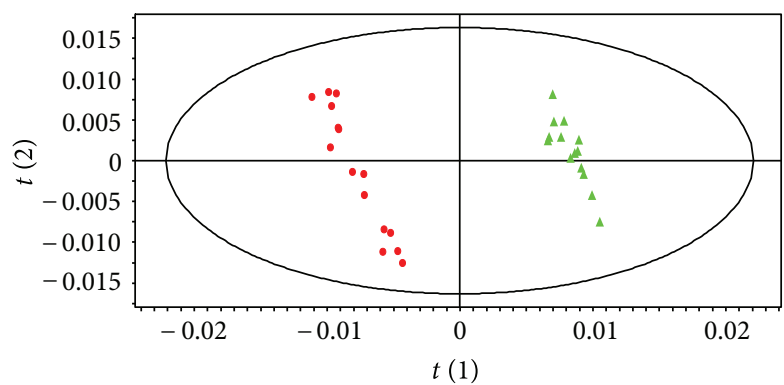

(c)

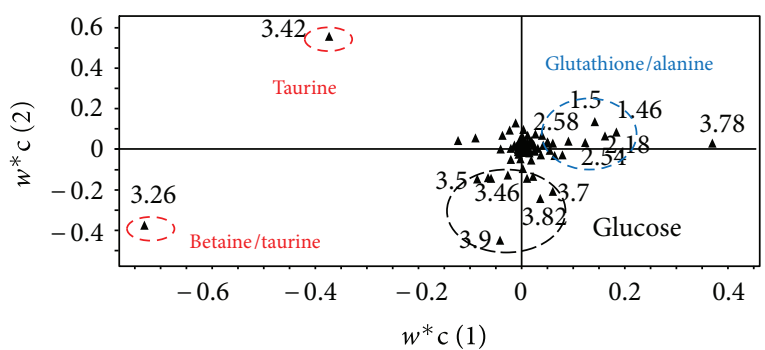

(d)

FIGURE 6: PLS-DA (a) score plot and (b) loading plot based on the ${ }^{1} \mathrm{H}$ NMR spectra of aqueous liver extract samples from nonexposed (blue diamond, $n=16)$ and exposed female mice (black square, $n=16)\left(Q^{2}=0.965, R^{2}=98.4 \%\right.$, and A $\left.=2\right)$. PLS-DA (c) score plot and (d) loading plot based on the ${ }^{1} \mathrm{H}$ NMR spectra of aqueous liver extract samples from nonexposed (green triangle, $n=14$ ) or exposed male (red circle, $n=15)\left(Q^{2}=0.93, R^{2}=99.1 \%\right.$, and $\left.\mathrm{A}=3\right)$.

toxicity, in the same way as the increase in creatine in females could reflect liver physiopathological change.

\subsection{Endosulfan-Induced Changes in Choline Metabolism.} Choline is synthesized by the liver. It plays an important role in the integrity and composition of cell membranes. Phosphocholine is the most abundant phospholipid in biological membranes and, together with other lipids, forms the characteristic bilayer structure of cells and regulates membrane integrity. Our results suggest that dietary exposure to low doses of endosulfan could lead to changes of haematopoietic cell membrane composition. Changes to the biochemistry of membrane lipids after treatment with endosulfan have also been observed by other authors $[38,39]$. Changes to the membrane composition of bone marrow cells could have a major impact on the proliferative activity of haematopoietic cells. The increased choline content may be also linked to increased cell division since choline values have been shown to be predictive of proliferative activity of glioma [40-42]. This point is currently under investigation in our lab.

At the plasma level, as choline is the main component of VLDL, the decreased level of choline in females upon exposure to endosulfan could be mediating the decrease of this plasma lipoprotein. Biochemical analysis of plasma also showed a significant increase in triglyceride content that could be linked with changes in choline and VLDL levels. This result is in agreement with the clear decrease of plasmatic glycerol levels in both genders since this metabolite is an indirect indicator of TG hydrolysis.
Choline is also a precursor for the synthesis of acetylcholine whose synthesis depends on the capture of choline in the blood. The level of circulating choline could have an impact at the neuronal level by accelerating neuronal transmission. This could be compared with the neurotoxicity of endosulfan which has been described elsewhere [43].

Taken together, these results suggest that dietary exposure to endosulfan even at low doses could interfere with a number of physiological processes that regulate cell division, lipid metabolism, and neuronal transmission.

4.3. Endosulfan-Induced Disturbance in Oxidative Stress Metabolism. The levels of oxidized glutathione in the liver were decreased in both males and females upon dietary exposure to endosulfan, suggesting a cellular response linked to oxidative stress, although it cannot be confirmed from the presented data. One the other hand no differences in reduced glutathione level have been observed between endosulfan exposed- and control group. Unchanged reduced glutathione levels between the two groups could be due to an efficient GSH generation in endosulfan-exposed animals through the increase of betaine level (trimethylglycine). Indeed betaine is a primary methyl donor for S-adenosylmethionine which is known to regulate glutathione concentrations under conditions of oxidative stress in the liver [44].

The decrease in oxidized glutathione levels in the liver of male mice was associated with a concomitant decrease in glutamine and glutamate in the liver upon endosulfan exposure. Glutamate is a precursor for synthesis of glutathione 
and in this way forms a part of the key antioxidant system. Glutamine and glutamate cycle back and forth, converting from one form to the other during normal body metabolism. Our results are in agreement with reports that endosulfan induces oxidative stress, particularly in male mice $[32,38$, 45], and studies are under investigation to confirm this hypothesis.

As a fuel for rapidly dividing cells, glutamine contributes towards a healthy immune system, especially in the rapid production of white blood cells during an infection. The increased level of glutamine in female mouse bone marrow upon endosulfan exposure could be linked with its impact on the immune system [46].

\section{Conclusion}

Our metabonomic approach has enabled the detection of metabolic disturbances following dietary exposure to a low dose of endosulfan. Here we show that these disturbances are associated with oxidative stress in the liver as well as changes in hepatic glucose metabolism.

Given the increase in plasma glucose levels following endosulfan exposure, we believe that metabonomics will prove to be a useful approach to characterize dietary exposure in human. These noninvasive methods will be highly valuable tools for assessing the real exposure to pesticides in epidemiological studies.

\section{Acknowledgments}

This work was supported by a grant from Agence Nationale de la Recherche (ANR) and from the Agence Nationale de Sécurité Sanitaire de l'Alimentation, de l'Environnement et du Travail (ANSES) in scientific programs coordinated by L. GametPayrastre.

\section{References}

[1] M. Merhi, H. Raynal, E. Cahuzac, F. Vinson, J. P. Cravedi, and L. Gamet-Payrastre, "Occupational exposure to pesticides and risk of hematopoietic cancers: meta-analysis of case-control studies," Cancer Causes and Control, vol. 18, no. 10, pp. 1209-1226, 2007.

[2] M. Mariscal-Arcas, C. Lopez-Martinez, A. Granada, N. Olea, M. L. Lorenzo-Tovar, and F. Olea-Serrano, "Organochlorine pesticides in umbilical cord blood serum of women from Southern Spain and adherence to the Mediterranean diet," Food and Chemical Toxicology, vol. 48, no. 5, pp. 1311-1315, 2010.

[3] EFSA, "2008 Annual report on pesticide residues according to article 32 of Regulation (EC) No. 396/2005," EFSA Journal, vol. 8, no. 7, p. 1646, 2010.

[4] M. H. Silva and S. L. Beauvais, "Human health risk assessment of endosulfan. I: toxicology and hazard identification," Regulatory Toxicology and Pharmacology, vol. 56, no. 1, pp. 4-17, 2010.

[5] WHO, The WHO Recommended Classification of Pesticides by Hazard and Guidelines to Classification 2000-2002, World Healthg Organisation, International Programme on Chemical Safety/Inter-Organisation Programme for Sound Management of Chemicals, Geneva, Switzerland, 2002.
[6] M. Bajpayee, A. K. Pandey, S. Zaidi et al., "DNA damage and mutagenicity induced by endosulfan and its metabolites," Environmental and Molecular Mutagenesis, vol. 47, no. 9, pp. 682-692, 2006.

[7] J. Varayoud, L. Monje, T. Bernhardt, M. Muñoz-de-Toro, E. H. Luque, and J. G. Ramos, "Endosulfan modulates estrogendependent genes like a non-uterotrophic dose of $17 \beta$-estradiol," Reproductive Toxicology, vol. 26, no. 2, pp. 138-145, 2008.

[8] P. K. Gupta and S. V. Chandra, "Toxicity of endosulfan after repeated oral administration to rats," Bulletin of Environmental Contamination and Toxicology, vol. 18, no. 3, pp. 378-384, 1977.

[9] R. Hack, E. Ebert, and K. H. Leist, "Chronic toxicity and carcinogenicity studies with the insecticide endosulfan in rats and mice," Food and Chemical Toxicology, vol. 33, no. 11, pp. 941-950, 1995.

[10] N. Sinha, R. Narayan, and D. K. Saxena, "Effect of endosulfan on the testis of growing rats," Bulletin of Environmental Contamination and Toxicology, vol. 58, no. 1, pp. 79-86, 1997.

[11] F. N. Bebe and M. Panemangalore, "Exposure to low doses of endosulfan and chlorpyrifos modifies endogenous antioxidants in tissues of rats," Journal of Environmental Science and Health $B$, vol. 38, no. 3, pp. 349-363, 2003.

[12] R. C. T. Casabar, P. C. Das, G. K. DeKrey et al., "Endosulfan induces CYP2B6 and CYP3A4 by activating the pregnane $\mathrm{X}$ receptor," Toxicology and Applied Pharmacology, vol. 245, no. 3, pp. 335-343, 2010.

[13] O. Ozmen, S. Sahinduran, and F. Mor, "Pathological and immunohistochemical examinations of the pancreas in subacute endosulfan toxicity in rabbits," Pancreas, vol. 39, no. 3, pp. 367-370, 2010.

[14] R. Pathak, S. G. Suke, T. Ahmed et al., "Organochlorine pesticide residue levels and oxidative stress in preterm delivery cases," Human and Experimental Toxicology, vol. 29, no. 5, pp. 351-358, 2010.

[15] T. Cabaleiro, A. Caride, A. Romero, and A. Lafuente, "Effects of in utero and lactational exposure to endosulfan in prefrontal cortex of male rats," Toxicology Letters, vol. 176, no. 1, pp. 58-67, 2008.

[16] J. K. Nicholson, J. C. Lindon, and E. Holmes, “Metabonomics': understanding the metabolic responses of living systems to pathophysiological stimuli via multivariate statistical analysis of biological NMR spectroscopic data," Xenobiotica, vol. 29, no. 11, pp. 1181-1189, 1999.

[17] K. A. Aliferis and M. Chrysayi-Tokousbalides, "Metabolomics in pesticide research and development: review and future perspectives," Metabolomics, vol. 7, no. 1, pp. 35-53, 2011.

[18] S. A. E. Brown, J. R. McKelvie, A. J. Simpson, and M. J. Simpson, ${ }^{~}{ }^{1} \mathrm{H}$ NMR metabolomics of earthworm exposure to sub-lethal concentrations of phenanthrene in soil," Environmental Pollution, vol. 158, no. 6, pp. 2117-2123, 2010.

[19] H. P. Wang, Y. J. Liang, D. X. Long, J. X. Chen, W. Y. Hou, and Y. J. Wu, "Metabolic profiles of serum from rats after subchronic exposure to chlorpyrifos and carbaryl," Chemical Research in Toxicology, vol. 22, no. 6, pp. 1026-1033, 2009.

[20] L. Wei, P. Liao, H. Wu et al., "Metabolic profiling studies on the toxicological effects of realgar in rats by ${ }^{1} \mathrm{H}$ NMR spectroscopy," Toxicology and Applied Pharmacology, vol. 234, no. 3, pp. 314-325, 2009.

[21] "Joint FAO/WHO meeting on pesticide residues: pesticide residues in food 2010," Report of the Joint Meeting of the FAO Panel of Experts OnPesticide Residues in Food and 
the Environment and the WHO Core Assessment Group on Pesticide Residues, Rome, Italy, September 2010.

[22] M. Merhi, C. Demur, C. Racaud-Sultan et al., "Gender-linked haematopoietic and metabolic disturbances induced by a pesticide mixture administered at low dose to mice," Toxicology, vol. 267, no. 1-3, pp. 80-90, 2010.

[23] J. Folch, I. Ascoli, M. Lees, J. A. Meath, and N. Le Baron, "Preparation of lipide extracts from brain tissue," The Journal of Biological Chemistry, vol. 191, no. 2, pp. 833-841, 1951.

[24] N. J. Waters, E. Holmes, C. J. Waterfield, R. D. Farrant, and J. K. Nicholson, "NMR and pattern recognition studies on liver extracts and intact livers from rats treated with $\alpha$ naphthylisothiocyanate," Biochemical Pharmacology, vol. 64, no. 1, pp. 67-77, 2002.

[25] J. A. Westerhuis, H. C. J. Hoefsloot, S. Smit et al., "Assessment of PLSDA cross validation," Metabolomics, vol. 4, no. 1, pp. 81-89, 2008.

[26] S. Wold, H. Antti, F. Lindgren, and J. Öhman, "Orthogonal signal correction of near-infrared spectra," Chemometrics and Intelligent Laboratory Systems, vol. 44, no. 1-2, pp. 175-185, 1998.

[27] I. Rana and T. Shivanandappa, "Mechanism of potentiation of endosulfan cytotoxicity by thiram in Ehrlich ascites tumor cells," Toxicology In Vitro, vol. 24, no. 1, pp. 40-44, 2010.

[28] M. Aggarwal, S. B. Naraharisetti, S. Dandapat, G. H. Degen, and J. K. Malik, "Perturbations in immune responses induced by concurrent subchronic exposure to arsenic and endosulfan," Toxicology, vol. 251, no. 1-3, pp. 51-60, 2008.

[29] P. R. Dalsenter, E. Dallegrave, J. R. B. Mello, A. Langeloh, R. T. Oliveira, and A. S. Faqi, "Reproductive effects of endosulfan on male offspring of rats exposed during pregnancy and lactation," Human and Experimental Toxicology, vol. 18, no. 9, pp. 583-589, 1999.

[30] T. Ahmed, R. Pathak, M. Mustafa et al., "Ameliorating effect of $\mathrm{N}$-acetylcysteine and curcumin on pesticide-induced oxidative DNA damage in human peripheral blood mononuclear cells," Environmental Monitoring and Assessment, vol. 179, no. 1-4, pp. 293-299, 2011.

[31] S. Ozdem, C. Nacitarhan, M. S. Gulay, F. S. Hatipoglu, and S. S. Ozdem, "The effect of ascorbic acid supplementation on endosulfan toxicity in rabbits," Toxicology and Industrial Health, vol. 27, no. 5, pp. 437-446, 2011.

[32] R. Saxena, P. Garg, and D. K. Jain, "In vitro anti-oxidant effect of vitamin e on oxidative stress induced due to pesticides in rat erythrocytes," Toxicology International, vol. 18, no. 1, pp. 73-76, 2011.

[33] F. Vinson, M. Merhi, I. Baldi, H. Raynal, and L. GametPayrastre, "Exposure to pesticides and risk of childhood cancer: a meta-analysis of recent epidemiological studies," Occupational and Environmental Medicine, vol. 68, no. 9, pp. 694-702, 2011.

[34] Y. Kalender, S. Kalender, M. Uzunhisarcikli, A. Ogutcu, F. Açikgoz, and D. Durak, "Effects of endosulfan on B cells of Langerhans islets in rat pancreas," Toxicology, vol. 200, no. 2-3, pp. 205-211, 2004.

[35] D. H. Lee, I. K. Lee, M. Porta, M. Steffes, and D. R. Jacobs Jr., "Relationship between serum concentrations of persistent organic pollutants and the prevalence of metabolic syndrome among non-diabetic adults: results from the national health and nutrition examination survey 1999-2002," Diabetologia, vol. 50, no. 9, pp. 1841-1851, 2007.
[36] H. J. Schirra, C. G. Anderson, W. J. Wilson et al., "Altered metabolism of growth hormone receptor mutant mice: a combined NMR metabonomics and microarray study," PLoS ONE, vol. 3, no. 7, Article ID e2764, 2008.

[37] T. O. Street, D. W. Bolen, and G. D. Rose, "A molecular mechanism for osmolyte-induced protein stability," Proceedings of the National Academy of Sciences of the United States of America, vol. 103, no. 38, pp. 13997-14002, 2006.

[38] N. S. El-Shenawy, "Effects of insecticides fenitrothion, endosulfan and abamectin on antioxidant parameters of isolated rat hepatocytes," Toxicology In Vitro, vol. 24, no. 4, pp. 1148-1157, 2010.

[39] S. Narayan, H. M. Dani, and U. K. Misra, "Changes in lipid profiles of liver microsomes of rats following intratracheal administration of DDT or endosulfan," Journal of Environmental Science and Health B, vol. 25, no. 2, pp. 243-257, 1990.

[40] D. Desoubzdanne, C. Claparols, N. Martins-Froment et al., "Analysis of hydrophilic and lipophilic choline compounds in radioresistant and radiosensitive glioblastoma cell lines by HILIC-ESI-MS/MS," Analytical and Bioanalytical Chemistry, vol. 398, no. 6, pp. 2723-2730, 2010.

[41] H. Shimizu, T. Kumabe, R. Shirane, and T. Yoshimoto, "Correlation between choline level measured by proton MR spectroscopy and Ki-67 labeling index in gliomas," American Journal of Neuroradiology, vol. 21, no. 4, pp. 659-665, 2000.

[42] Q. Zhang, J. Z. Hu, D. N. Rommereim et al., "Application of high-resolution ${ }^{1} \mathrm{H}$ MAS NMR spectroscopy to the analysis of intact bones from mice exposed to gamma radiation," Radiation research, vol. 172, no. 5, pp. 607-616, 2009.

[43] M. H. Silva and D. Gammon, "An assessment of the developmental, reproductive, and neurotoxicity of endosulfan," Birth Defects Research B, vol. 86, no. 1, pp. 1-28, 2009.

[44] J. A. Gonzalez-Correa, J. P. De La Cruz, E. Martin-Aurioles, M. A. Lopez-Egea, P. Ortiz, and F. Sanchez De La Cuesta, "Effects of S-adenosyl-L-methionine on hepatic and renal oxidative stress in an experimental model of acute biliary obstruction in rats," Hepatology, vol. 26, no. 1, pp. 121-127, 1997.

[45] F. Hincal, A. Gurbay, and B. Giray, "Induction of lipid peroxidation and alteration of glutathione redox status by endosulfan," Biological Trace Element Research, vol. 47, no. 1-3, pp. 321-326, 1995.

[46] B. D. Banerjee and Q. Z. Hussain, "Effect of sub-chronic endosulfan exposure on humoral and cell-mediated immune responses in albino rats," Archives of Toxicology, vol. 59, no. 4, pp. 279-284, 1986. 

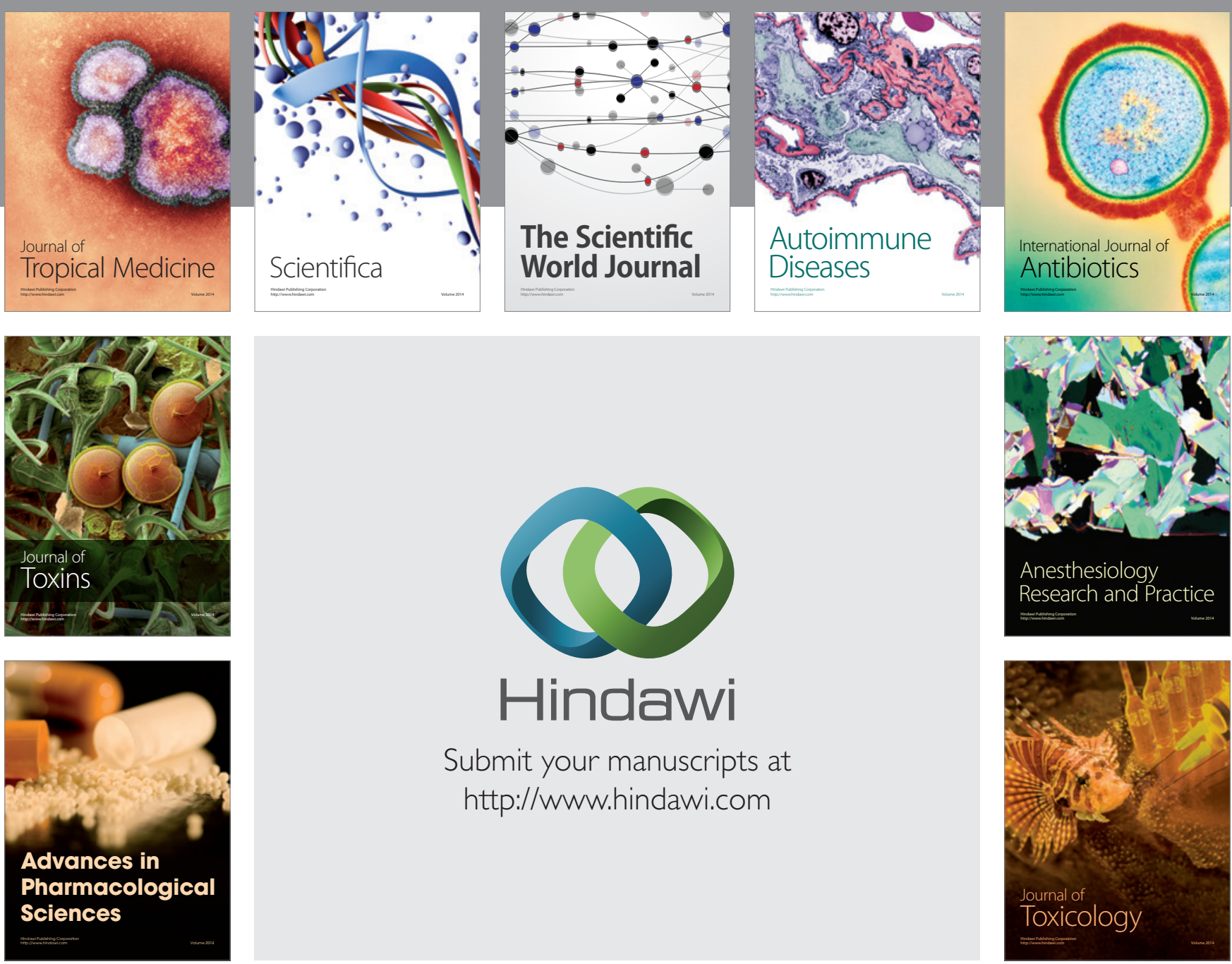

\section{Hindawi}

Submit your manuscripts at

http://www.hindawi.com
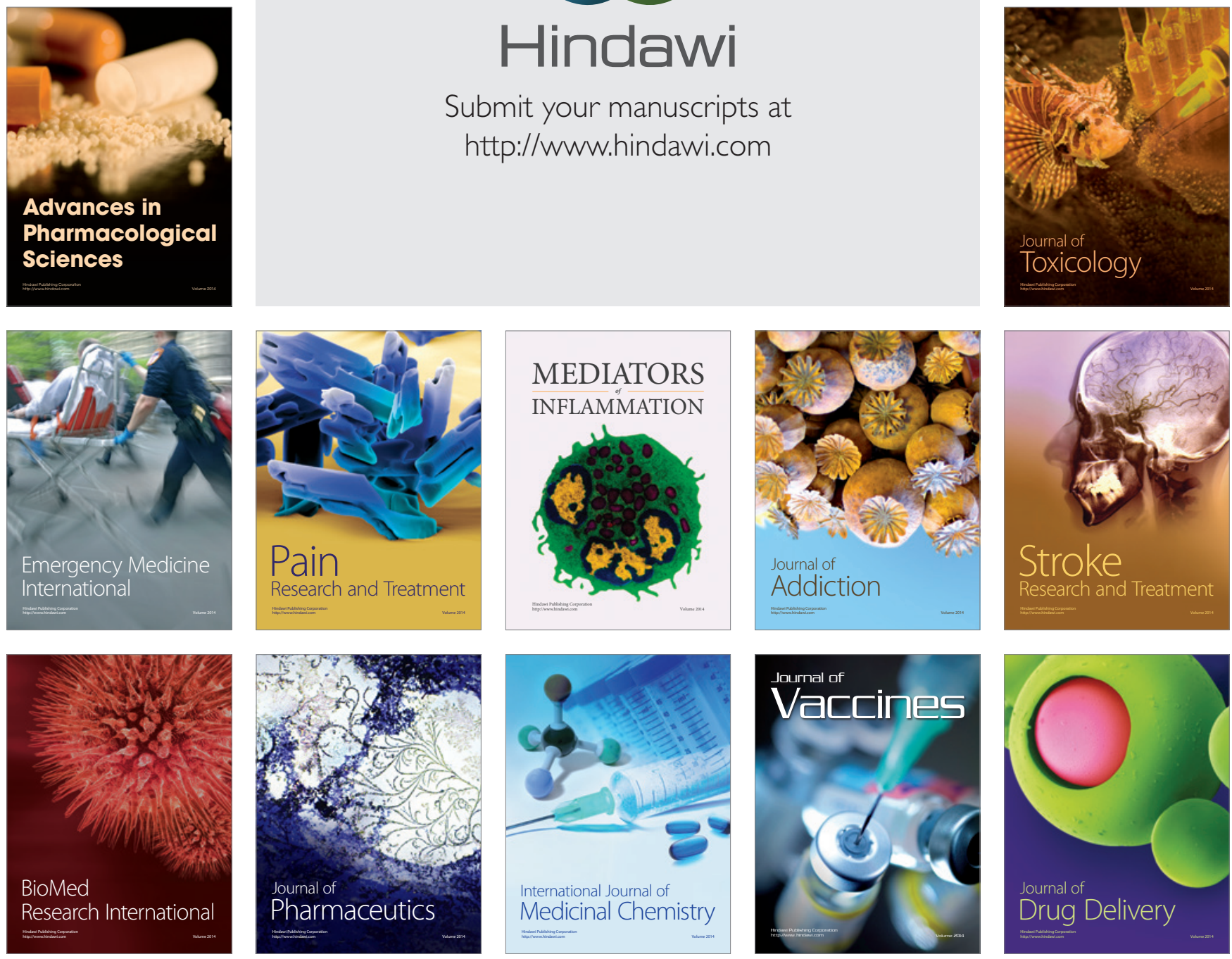